\title{
Gender Gap in Upward Mobility: What is the Role of Non-Cognitive Traits?
}

\author{
Yu-Wei Luke Chu \\ Luke.Chu@vuw.ac.nz \\ School of Economics and Finance \\ Victoria University of Wellington
}

\author{
Susan J. Linz \\ linz@msu.edu \\ Department of Economics \\ Michigan State University
}

\begin{abstract}
Do non-cognitive traits contribute to the gender gap in supervisory status and promotion? We use a large employer-employee matched dataset collected from six former socialist countries to assess the link between non-cognitive traits and upward mobility. Controlling for workplace heterogeneity, we find that gender differences in locus of control, the preference for challenge versus affiliation, and adherence to work ethic together can explain about $7-18 \%$ of the gender gap in supervisory status and promotion. Overall, non-cognitive traits provide an important, though modest, explanation for the gender gap in upward mobility.
\end{abstract}

Keywords: gender gap, upward mobility, personality, work ethic, supervisor, promotion

JEL Classification: J16, J24, J60, J53, P20 


\section{Introduction}

Despite decades of legislation aimed at promoting equality, women worldwide hold only $22 \%$ of the senior management positions (Thornton 2015). A gender gap in upward mobility remains well-documented in the social science and management literatures. Women are much less likely than men to occupy supervisory positions; promotion rates are lower for women than for men (Blau and DeVaro 2007; Johnston and Lee 2012; Pekkarinen and Vartiainen 2006). Empirical studies uniformly indicate that the upward mobility gap cannot be entirely explained by gender differences in conventional worker and workplace characteristics. Consequently, the logical question arises: How important are unconventional worker characteristics such as non-cognitive traits in explaining the ubiquitous and persistent nature of the gender gap in upward mobility?

To investigate the link between non-cognitive traits and upward mobility, we utilize employer-employee matched survey data collected in six formerly-socialist economies (Armenia, Azerbaijan, Kazakhstan, Kyrgyzstan, Russia, and Serbia). While our sample is not representative of employees or workplaces in the countries where the survey was conducted due to financial constraints, our data contain an extensive set of worker characteristics and allow us to control for workplace fixed effects to account for unobserved workplace heterogeneity. Since we are working with convenience samples, we limit our discussion of results to survey participants, refraining from generalizing to some broader population. We focus on three commonly used measures of non-cognitive traits: locus of control (LOC), preference for challenge versus affiliation (C-A), and adherence to work ethic (WE). Our primary measure of upward mobility is supervisory status. Holding a supervisory position assumes significant types of responsibilities and decision-making authority, reflecting upward movement in one's career. Promotion is another common measure of upward mobility. Like Blau and DeVaro (2007), our data contain information on promotions received at current workplace which may not fully reflect all promotions received. Therefore, we view promotion as secondary to supervisory status as a measure of upward mobility.

As common in the literature, women in our survey exhibit less favorable noncognitive traits in comparison to men. The participating female employees have a stronger external locus of control, a preference for affiliation over challenge, and a weaker adherence to work ethic. Yet, regression analysis suggests that internal locus of control, preference for challenge, and stronger adherence to work ethic are positively 
associated with supervisory status and promotion. While incorporating these three noncognitive traits explains an additional $7-17 \%$ of the estimated gender gap conditional on worker characteristics and workplace fixed effects, a significant gender gap in upward mobility remains unexplained. Similarly, the Oaxaca-Blinder decomposition shows that gender differences in LOC, C-A, and WE together can explain 8-18\% of the gender gap in supervisory status or promotion. That is, including these three noncognitive traits significantly increases the proportion of the explained gender gap from $15 \%$ to $22 \%$ for supervisory status, and $9 \%$ to $25 \%$ for promotion. However, about three-quarters of the total gender gap remains unexplained, suggesting additional research and more extensive data are warranted. Like gender pay gap studies (CobbClark and Tan 2011; Fortin 2008; Grove, Hussey, and Jetter 2011; Manning and Swaffield 2008; Mueller and Plug 2006; Semykina and Linz 2007, 2010), our results suggest that non-cognitive traits account for a significant, albeit modest, role in explaining the gender gap in upward mobility.

Our analysis of the link between non-cognitive traits and the gender gap in upward mobility proceeds as follows: we describe the sample selection and sample characteristics in Section 2, and the construction of the non-cognitive traits in Section 3. We discuss our methodology in Section 4. Regression results and results from the Oaxaca-Blinder decomposition are presented in Section 5. Section 6 offers a summary of our findings and concluding remarks.

\section{Data Description and Sample Characteristics}

Our data come from an employee survey designed to investigate factors influencing worker performance. The survey was conducted in large and small metropolitan areas in Russia, Armenia, Azerbaijan, Kazakhstan, Kyrgyzstan and Serbia. Local project coordinators, originally using their professional contacts and then pursuing a snowballing technique, contacted over 700 workplaces to obtain permission to conduct the survey. Altogether, more than 10,880 employees in over 665 workplaces participated. While not representative of employees nationally, nor representative of employees within a particular workplace, the convenience samples in each country do represent a wide variety of workers and workplaces from multiple geographic locations.

Restricting the sample to include only those participants who answered all questions relevant to this analysis yields a total of 7,502 employees $(7,460$ employees 
for supervisory status) from 567 workplaces. ${ }^{1}$ Descriptive statistics for worker characteristics are presented in the top panel of Table 1. On average, participating employees are 36.7 years old, and have completed 14.6 years of education. Some $57 \%$ are female; more than half are married. Workplace tenure at their primary firm averages slightly more than seven years. Just over $12 \%$ hold multiple jobs; one-third experienced unemployment in the five year period prior to the survey. To proxy for productivity and cognitive abilities, we constructed a composite measure of self-reported performance. (See Appendix Table A1.) One-third of the participating employees report themselves as holding a supervisory position, and nearly half (48\%) report having received at least one promotion at their current workplace.

In terms of gender differences among our participating employees, women are slightly older and exhibit a significantly longer workplace tenure. Men are more likely to report holding multiple jobs and self report their performance higher. While no gender difference in promotion is evident, men are significantly more likely to hold a supervisory position.

The distribution of participating employees across workplace types is presented in the lower panel of Table 1. Less than half (44\%) are employed in state-owned organizations. Most are employed in manufacturing plants, retail service, public sectors, and education and health care organizations, with relatively few employed in construction/transportation or finance.

\section{Measures of Non-Cognitive Traits}

\subsection{Locus of Control}

Locus of control (LOC) is a measure of expectancy; one's assessment that one's actions will lead to desired outcomes. Individuals exhibiting an internal LOC expect a direct connection between effort and desired goals; those exhibiting an external LOC do not. Compelling evidence links having an internal LOC to career success. [See a review article by Cobb-Clark (2015).] Workers with an internal LOC tend to have higher earnings (Cebi 2007; Dunifon and Duncan 1998), exhibit higher job satisfaction and performance (Judge and Bono 2001; Linz and Semykina 2009, 2011), seek out more complex jobs (Judge, Bono, and Locke 2000), and tend to set more challenging

\footnotetext{
${ }^{1}$ The final sample includes 1,577 participants in Armenia, 1,048 in Azerbaijan, 714 in Kazakhstan, 1,261 in Kyrgyzstan, 1,929 in Russia, and 973 in Serbia.
} 
goals (Ng, Sorensen, and Eby 2006; Wang, Bowling, and Eschleman 2010). We therefore hypothesize that participants in our survey with an internal LOC are more likely to hold a supervisory position and/or receive promotion.

We use ten statements taken from Rotter (1966) to construct our LOC measure. As seen in Table 2, five statements address the belief that an individual has control over his/her fate; five statements address the opposite belief. For each statement, participants are given a scale from 1 (strongly disagree) to 5 (strongly agree). The composite measure is constructed for each participant by summing the five internal components, summing the five external components, and then subtracting the external score from the internal score. To facilitate comparison with other non-cognitive traits (also composite measures), we re-scale the LOC measure such that the lowest possible value (most external) is zero and the highest possible value (most internal) is one. The reliability coefficients (Cronbach alpha) for the LOC measure for the pooled sample and by gender are around 0.60, within the conventional acceptable range.

As seen in Table 2, participating male workers tend to exhibit a relatively internal LOC, while participating female workers exhibit a relatively external LOC. In terms of one standard deviation, participating male workers score on average $12 \%$ $(0.015 / 0.128)$ higher on the LOC measure than female workers. These findings are consistent with the majority of studies in psychology that find males more internal than females on the LOC measure. [See Sherman, Higgs, and Williams (1997) for a metaanalysis on gender difference in LOC.]

\subsection{Challenge versus Affiliation}

To construct the challenge-affiliation (C-A) measure, we utilize four questions similar to those employed by Dunifon and Duncan (1998) in the Panel Study of Income Dynamic. Traditionally, individuals with a strong preference for challenge are considered to be more highly motivated than those with preference for affiliation. Indeed, previous research has shown that preference for challenge is associated with higher earnings and better work performance (Dunifon and Duncan 1998; Linz and Semykina 2009, 2011; Semykina and Linz 2007). However, the dichotomous opposition of challenge (get ahead) and affiliation (get along) may ignore the importance of such 'soft skills' as communication skills and teamwork which may also play prominently in upward mobility (Duncan and Dunifon 2012). In particular, upward mobility may rely more on soft skills than do earnings because, for example, a person 
who tries only to 'get ahead' and/or cannot 'get along' with fellow co-workers is unlikely to be a good supervisor. Therefore, we are neutral as to whether the preference for challenge over affiliation is positively linked to the likelihood of being a supervisor or receiving promotion.

As seen in Table 3, the first two statements indicate preference for challenge, while the latter two statements indicate preference for affiliation. In each case, participants were given a scale from 1 (strongly disagree) to 5 (strongly agree). For each participant, a C-A score is calculated by subtracting the combined score of the two affiliation components from the combined score of the two challenge components. To facilitate comparison, the C-A measure is then re-scaled within the unit interval. The C-A reliability coefficients (Cronbach alpha) for the pooled sample and by gender are 0.63, again within the conventional acceptable range. As seen in Table 3, in terms of one standard deviation, participating male workers score $5 \%(0.006 / 0.126)$ higher on the C-A composite measure than female workers, indicating a stronger preference for challenge.

\subsection{Work Ethic}

Movement up the occupational ladder is linked directly to one's attitude toward the value of work. Empirical studies of work values tend to focus on work ethic (WE) - a commitment to the values of hard work, achievement, thrift, discipline, and selfreliance. WE is not tied to any set of religious beliefs, although it often is referred to as the 'Protestant Work Ethic.' Strong adherence to work ethic suggests an employee appreciates the value of work and is motivated to do her job. Research has shown that work ethic is positively correlated with earnings (Linz and Chu 2014), as well as with job satisfaction and work commitment (Lee, Carswell, and Allen 2000; Miller, Woehr, and Hudspeth 2002; Vansteenkiste et al. 2007; Yousef 2001). Moreover, strong work ethic is associated with enterprising vocational preferences (Berings, De Fruyt, and Bouwen 2004; Bonnett and Furnham 1991). Consequently, we hypothesize that strong adherence to work ethic increases the likelihood of being a supervisor or receiving promotion.

Our work ethic measure is based on Blood (1969) and includes eight components. As seen in Table 4, four components indicate stronger work ethic, and four components indicate weaker work ethic. For each statement, participants are given a scale from 1 (strongly disagree) to 5 (strongly agree). We create a composite measure 
of WE by taking the difference between the total score of the four positively-worded components and the total score of the four negatively-worded components; thus a higher score indicates stronger adherence. We then re-scale the WE measure to be within the unit interval. The reliability coefficients (Cronbach alpha) for the pooled sample and by gender are 0.50 . Relatively low reliability coefficients for WE measures are common in the literature; Abdalla (1997) and Furnham (1990), among others, report similarly low scores. In fact, some studies suggest that work ethic consists of several conceptually distinct dimensions and thus should be a multidimensional construct rather than a single composite measure (Meriac, Poling, and Woehr 2009; Miller, Woehr, and Hudspeth 2002). Since no resolution has emerged in the literature, we continue the convention of using the single composite measure.

Table 4 shows that, compared to participating female employees, male employees are more likely to agree with the statements indicating a strong work ethic and less likely to agree with the statements indicating weak work ethic. On average, in terms of one standard deviation, males score $18 \%(0.021 / 0.115)$ higher on the WE measure than females. These findings are consistent with many studies that show men adhere more strongly to a particular work ethic measure than women (Ali, Falcone, and Azim 1995; Boatwright and Slate 2000; Kirkcaldy, Furnham, and Lynn 1992; Wentworth and Chell 1997). ${ }^{2}$

\section{Methodology}

\subsection{Regression Analysis}

To document the gender gap in upward mobility, we start by estimating a linear probability model by OLS as follows:

$$
Y_{i j}=\alpha+\beta \text { gender }_{i}+\delta \text { worker characteristics }{ }_{i}+\lambda \text { workplace fixed effects }_{j}+\varepsilon_{i j},
$$

where $Y_{i j}$ is a dummy variable indicating whether individual $i$ holds a supervisory position or receives a promotion at the current workplace $j$. The coefficient $\beta$ measures the gender gap in supervisory status, conditional on worker characteristics and workplace fixed effects. $\delta$ is the vector of coefficients associated with worker

\footnotetext{
${ }^{2}$ The findings on gender difference in work ethic are mixed. Some studies suggest no gender difference (Meriac, Poling, and Woehr 2009; Rowe and Snizek 1995), or that women adhere more strongly than men (Ghorpade, Lackritz, and Singh 2006; Mann 2010).
} 
characteristics: age and its square, years of schooling, workplace tenure and its square, and dummy variables for marital status, unemployment experience in the five years prior to participating in the survey, and whether participant holds multiple jobs. Additionally, similar to Blau and DeVaro (2007), self-reported performance is included, re-scaled to be between 0 and 1 to be comparable with other composite measures. (See Appendix Table A1). We take advantage of our employer-employee linked data and control for workplace fixed effects in the model to account for both observed and unobserved firm differences. Effectively, we only compare employees at the same workplaces.

To identify the link between non-cognitive traits and upward mobility, and the associated changes in gender gap, we extend the model to include the three noncognitive traits described above:

$$
\begin{aligned}
Y_{i j}=\alpha+\beta \text { gender }_{i}+\gamma_{1} C-A_{i}+\gamma_{2} L O C_{i}+\gamma_{3} W E_{i} & +\delta \text { worker characteristics }_{i} \\
& +\lambda \text { workplace fixed effect } s_{j}+\varepsilon_{i j},
\end{aligned}
$$

where $\gamma_{1}-\gamma_{3}$ captures the effects of non-cognitive traits on supervisory status or promotion, and $\beta$ captures the gender gap conditional on worker characteristics, noncognitive traits, and workplace heterogeneity. We use the re-scaled measures of these non-cognitive traits in the regression so the estimates of $\gamma_{1}-\gamma_{3}$ are directly comparable. Because significant gender differences in these non-cognitive traits are evident among the survey participants (see Tables 2-4), we would expect $\beta$ in Equation (2) to be smaller than in Equation (1) if some of the gender gap in supervisory status (or promotion) is explained away by gender differences in non-cognitive traits. Elder, Goddeeris, and Haider (2010) show that the coefficient on the gender dummy from the OLS regression is a good single measure of the unexplained gap. If the gender gap were largely due to differences in non-cognitive traits, the estimate of $\beta$ should become much smaller as the unexplained gap is reduced by the inclusion of non-cognitive traits. Therefore, the percentage decrease in the estimate of $\beta$ can be interpreted as the proportion of gender gap explained by non-cognitive traits and the relative importance of non-cognitive traits.

Throughout this analysis, we cluster the estimated standard errors at the firm level so they are robust to any within-firm correlation and heteroskedasticity. 


\subsection{Oaxaca-Blinder Decomposition}

In this section, we propose the Oaxaca-Blinder decomposition that accounts for workplace heterogeneity. As our main variables of interest are worker characteristics, we first regress each of our two dependent variables and worker-level explanatory variables on the workplace fixed effects, obtain the residuals, and then use the residuals to perform a detailed "twofold" decomposition as follows ${ }^{3}$ :

$$
\overline{\ddot{Y}}_{m}-\overline{\ddot{Y}}_{f}=\left(\overline{\mathbf{X}}_{m}-\overline{\mathbf{X}}_{f}\right) \hat{\boldsymbol{\beta}}+\overline{\ddot{X}}_{m}\left(\widehat{\boldsymbol{\beta}}_{m}-\widehat{\boldsymbol{\beta}}\right)+\overline{\mathbf{X}}_{f}\left(\widehat{\boldsymbol{\beta}}-\widehat{\boldsymbol{\beta}}_{f}\right)
$$

where bars denote sample averages, the double dots denote the residuals of the dependent and explanatory variables, and subscripts $m$ and $f$ denote males and females. $\widehat{\boldsymbol{\beta}}$ is the vector of estimates from the pooled regression of all employees such as Equation (2). ${ }^{4} \widehat{\boldsymbol{\beta}}_{m}$ and $\widehat{\boldsymbol{\beta}}_{f}$ are the vectors of gender-specific estimates obtained from the OLS regressions using only male or female employees. The first component, $\left(\overline{\mathbf{X}}_{m}-\overline{\mathbf{X}}_{f}\right) \hat{\boldsymbol{\beta}}$, is the explained part of the gender gap that is accounted by gender meandifferences in the (residuals of) explanatory variables. The second component, $\ddot{\mathbf{X}}_{m}\left(\widehat{\boldsymbol{\beta}}_{m}-\widehat{\boldsymbol{\beta}}\right)+\ddot{\mathbf{X}}_{f}\left(\widehat{\boldsymbol{\beta}}-\widehat{\boldsymbol{\beta}}_{f}\right)$, is the unexplained part of the gender gap that comes from the gender differences in the estimates of coefficients (including difference in the intercept). We perform the Oaxaca-Blinder decomposition and calculate the estimated standard errors using the estimators provided by Jann (2008). The estimated standard errors are also clustered at the workplace level.

\section{Results}

\subsection{Results from OLS Regressions}

Table 5 summarizes the regression results for supervisory status [columns (1) and (2)] and promotion [columns (3) and (4)]. To make the interpretation easier, we scale the estimates and estimated standard errors by 100 and thus they reflect differences in percentage points. ${ }^{5}$

\footnotetext{
${ }^{3}$ Appendix Table A2 shows gender mean-differences in these residuals.

${ }^{4}$ An application of the Frisch-Waugh-Lovell theorem suggests that the OLS estimates from a fixed effects regression are numerically identical to the OLS estimates from regressing the residuals of the dependent variable on the residuals of the explanatory variables after partialling out the fixed effects. ${ }^{5}$ Appendix Table A3 and A4 present average partial effects from probit and logit models.
} 
Column (1) shows that participating females are 10.1 percentage points less likely than participating males with similar characteristics working in their same organization to be a supervisor. The estimates for the conventional worker characteristics are as expected. We find that the likelihood of being a supervisor increases with age and workplace tenure but at a decreasing rate. Married workers and workers holding multiple job, both more likely to be male, are more likely to be a supervisor, while workers with unemployment experience are less likely to be a supervisor. Column (1) also shows that education and self-reported performance are strong predictors of holding a supervisory position. One additional year of schooling is associated with a 2.1 percentage point increase in the probability of being a supervisor. One standard deviation higher in self-reported performance is associated with a 7.3 $(50.00 \times 0.146)$ percentage point increase in the probability of being a supervisor.

When the three non-cognitive traits are included [column (2)], women are 9.3 percentage points less likely to be a supervisor than comparable men who work in the same organization. We find that most of the estimates for worker characteristics remain quantitatively similar. For example, in column (2), one additional year of schooling is associated with a 2.0 percentage point increase in the probability of being a supervisor; one standard deviation higher in self-reported performance is associated with a 6.7 $(45.81 \times 0.146)$ percentage point increase in the probability of being a supervisor. This suggests, first, that these non-cognitive traits are not strongly correlated with other explanatory variables in determining supervisory status, and, second, that they capture variation unexplained by conventional explanatory variables. Because explanatory variables like education and performance are typically considered to reflect cognitive abilities and productivity, if our measures of non-cognitive traits were strongly correlated with these explanatory variables, we would be concerned that they may instead be capturing cognitive abilities. Instead, our results provide strong support for LOC, C-A, and WE as appropriate measures of non-cognitive traits.

As seen in Table 5, all estimates for non-cognitive traits are positive and statistically significant, with WE as the strongest predictor of being a supervisor. Our estimate suggests that a one standard deviation increase in WE leads to an increase in the likelihood of holding a supervisory position by $3.2(28.09 \times 0.115)$ percentage points. As one-third of the participating employees hold a supervisory position, this estimate is equivalent to a $10 \%$ increase in the probability of being a supervisor. For workers who score one standard deviation higher in C-A and therefore value challenge 
more than affiliation in a work environment, they are $2.3(18.63 \times 0.126)$ percentage points more likely to hold a supervisory position ( $8 \%$ increase). Participating employees who score one standard deviation higher in LOC (exhibit more internal locus of control), are $2.1(16.49 \times 0.128)$ percentage points more likely to hold a supervisory position (6\% increase).

How important are these non-cognitive traits in explaining the gender gap in the likelihood of holding a supervisory position? Recall that the OLS estimate for the gender indicator can be interpreted as a measurement of the unexplained gender gap because the parts of gender gap that can be explained by explanatory variables in the regression have been partialled out. We can therefore take the changes in the estimates for the gender indicator from column (1) to column (2) as a measure of the importance of non-cognitive traits in explaining the gender gap. Conditional on the worker characteristics and workplace heterogeneity, non-cognitive traits included in this analysis explain away $8 \%\left(\frac{10.1-9.3}{10.1}\right)$ of the estimated gender gap in supervisory status.

Table 5 also presents the regression results for promotion, with [column (4)] and without [column (3)] non-cognitive traits. As seen in column (4), a gender gap in promotion of 2.8 percentage points emerges when the non-cognitive traits are included. Our estimates (around 3 percentage points gender gap) are of the same magnitude as those reported by Blau and DeVaro (2007) and Johnston and Lee (2012). The estimates for conventional worker characteristics show a pattern similar to the results for supervisory status. For example, the likelihood of promotion increases with workplace tenure but at a decreasing rate; workers holding multiple jobs are more likely to be promoted; workers with unemployment experience are significantly less likely. We find that education and performance, variables often used to proxy for cognitive abilities, are strong predictors of receiving promotion. One additional year of schooling is associated with a 2.0 percentage point increase in the probability of receiving promotion. One standard deviation higher in self-report performance is associated with a 5.0 (34.02 $\times 0.146$ ) percentage point increase in the probability of promotion.

As seen in column (4), both C-A and WE have positive effects on the likelihood of receiving promotion. For workers who have preference for challenge over affiliation, the estimates suggest that one standard deviation increase in C-A leads to an increase in the likelihood of receiving at least one promotion by $2.9(23.39 \times 0.126)$ percentage points $(6 \%$ increase). For workers who more strongly adhere to work ethic, the 
estimates indicate that one standard deviation increase in WE leads to an increase in the likelihood of receiving promotion by $1.5(13.39 \times 0.115)$ percentage points $(3 \%$ increase). In contrast, the estimate for LOC is small and insignificant; LOC does not appear to be a strong predictor of promotion. The effects of non-cognitive traits on promotion appear to be somewhat smaller than on supervisory status, which could be due to the truncated information on promotion. For example, workers with favorable non-cognitive traits may have better outside opportunities and therefore they are more likely to move to other firms.

How important are these non-cognitive traits in explaining the gender gap in the likelihood of promotion? From column (3) to column (4), conditional on the observed worker characteristics and workplace heterogeneity, the non-cognitive traits can explain away $17 \%\left(\frac{3.3-2.8}{3.3}\right)$ of the estimated gender gap in promotion.

Notice that, by taking difference between the positive and negative components, our composite measures for non-cognitive traits have the advantage of accounting for individual reporting behaviors. However, one concern is that the positive and the negative components may not necessarily affect upward mobility in the opposite directions. For example, as discussed earlier, preference for affiliation may reflect soft skills and therefore could increase the likelihood of upward mobility. To check the validity of our composite measures, in Table 6, we replace all composite measures, including self-report performance, by each of their individual components. (Each positive/negative component is re-scaled in the unit interval.) We find that the estimates for internal LOC and positive WE are positive and significant, the estimates for external LOC and negative WE are negative and significant, and the estimate magnitudes are about the same for both the positive and negative components [see column (1)]. Our estimates show that these opposite components of LOC and WE indeed capture the same non-cognitive traits. For the components in C-A, the estimate for preference for challenge is positive and significant, while the estimate for affiliation is close to zero and insignificant. Therefore, $\mathrm{C}-\mathrm{A}$ is still a valid composite measure because the preference for affiliation does not actually increase upward mobility in our sample. Moreover, all of the three components of self-reported performance (anticipate and prevent problem, quality of work performance, and productivity) increase the likelihood of being a supervisor, suggesting that they comprise an internally consistent 
composite measure. ${ }^{6}$ The results for promotion are qualitatively similar [see column (2)], although the estimates are somewhat noisier. In general, the results in Table 6 are consistent with those in Table 5 and support the use of composite measures. As a robustness check, we estimate the models by ownership structure (state vs non-state owned organizations), and find little difference in the estimates for non-cognitive traits and the share of the gender gap explained by non-cognitive traits across types of ownership (see Appendix Table A5).

\subsection{Results from the Oaxaca-Blinder Decomposition}

Table 7 reports the Oaxaca-Blinder decomposition on the gender gap in supervisory status based on Equation (3). We scale the estimates and estimated standard errors by 100 as in the previous tables. For comparison, in the upper panel, we present both the total decomposition with and without the non-cognitive traits. In the lower panel, we show the detailed decomposition for each of the worker characteristics and non-cognitive traits. Column (1) shows that the total gender gap in holding a supervisory position is 8.7 percentage points higher for men (conditional on workplace fixed effects). In column (2), the upper panel indicates that, when the non-cognitive traits are included in the model, the explained gender gap increases from 1.3 percentage points to 1.9 percentage points, or equivalently, from $15 \%$ to $22 \%$, as measured in terms of the proportion of the total gender gap.

Non-cognitive traits account for a large proportion of the explained gender gap. In column (2), for the explained part of the gender gap, all estimates for non-cognitive traits are statistically significant. The gender mean-differences in LOC, C-A, and WE together contribute to the gender gap by 0.7 percentage points, which amounts to $36 \%$ $(0.68 / 1.91=0.36)$ of the explained gender gap. In terms of the total gender gap, the gender mean-difference in these non-cognitive traits can account for $8 \%$ of the total gender gap in the likelihood of being a supervisor. The two variables most related to cognitive abilities - education and performance - account for the same proportion of the gender gap as the non-cognitive traits. The estimate in column (2) indicates that gender difference in education explains a large amount of gender gap in supervisory

\footnotetext{
${ }^{6}$ Notice that for "quality of work performance," our estimate of 18.7 percentage points in column (2) is very close to Blau and DeVaro's (2007) estimates of around 19.5 percentage points that are based on employer-report performance rating. So our subjective performance measure is indeed comparable with objective measures.
} 
status. ${ }^{7}$ The gender difference in performance is also important but imprecisely estimated (not statistically significant). The gender mean-differences in years of schooling and performance together contribute 0.7 percentage points to the gender gap, which is equivalent to $37 \%$ of the explained gender gap, or $8 \%$ of the total gender gap in supervisory status. For the rest of worker characteristics in column (2), their meandifferences together explain 0.5 percentage points of the gender gap, which is equivalent to $27 \%$ of the explained gender gap, or $6 \%$ of the total gender gap.

Column (3) shows the unexplained gender gap, that part of gender gap due to gender differences in regression coefficients which cannot be explained by gender differences in the means. In the lower panel, nearly all of the estimates are small and insignificant, which implies little gender difference in most of the regression coefficients for these worker characteristics. In fact, except for the intercept term, the sum of all these estimates is close to zero. There appears to be little discrimination against women in observed worker characteristics; in terms of the likelihood of being a supervisor, women receive similar returns as their male counterparts from performance, personality, work ethic, and so forth. The estimate for the intercept term accounts for all of the unexplained gender gap, or equivalently, $78 \%$ of the total gender gap in supervisory status. Because the intercept term captures all of the gender differences in unobservables, the majority of the gender gap in supervisory status is due to unknown factors that are not captured by our explanatory variables. Notice that, although we have controlled for differences across firms, discrimination within a firm, for example, vertical segregation, could still be driving the results here.

Table 8 reports the Oaxaca-Blinder decomposition on the gender gap in promotion. Column (1) shows that the likelihood of receiving promotions for men is 2.6 percentage points higher than for women. In column (2), in the upper panel, the inclusion of non-cognitive traits increases the explained gender gap from 0.3 percentage points to 0.7 percentage points, or in terms of the proportion of the total gender gap, $9 \%$ to $25 \%$.

Perhaps because we only have information on promotions received at the current workplace, workplace tenure is a very strong predictor for the likelihood of promotion. Also because women have longer workplace tenure than men, which works

\footnotetext{
${ }^{7}$ While the gender difference in education is small and insignificant in Table 1, in Appendix Table A2, the gender difference in the residuals of education equals $8 \%$ of one standard deviation.
} 
in favor of women and reduces gender gap in promotion, the estimate for workplace tenure in column (2) is large and negative. As a result, in column (2), the sum of the gender mean-differences in education, performance, and non-cognitive traits is actually greater than the total explained gender gap. Consequently, we discuss the magnitudes only in terms of the proportion of the total gender gap. These non-cognitive traits account for a larger part of the gender gap in promotion than they do in supervisory status. In column (2), lower panel, the gender mean-differences in LOC (not statistically significant), C-A, and WE together contribute to the gender gap in promotion by 0.5 percentage points, which is equivalent to $18 \%$ of the total gender gap. The gender meandifferences in education and performance (not statistically significant) account for a bit more of the total gender gap than do non-cognitive traits, and together they contribute 0.6 percentage points to the gender gap, which amounts to about $23 \%$ of the total gender gap in promotion. As with supervisory status (Table 7), the majority of the gender gap in promotion (Table 8) is not explained by gender mean-differences in worker-level explanatory variables. Column (3) shows little gender difference in the coefficients of worker characteristics, except for the intercept term; the gender difference in the intercept term accounts for $75 \%$ of the total gender gap in promotion.

\section{Discussion and Conclusion}

To summarize, we document significant gender mean-differences in LOC, C-A, and WE, and show that gender differences in these non-cognitive traits can explain $7-$ $17 \%$ of the observed gender gap in upward mobility among the participants in our survey. We note that our results are very close to Johnston and Lee (2012) who show that controlling for the Big Five personality traits reduces the estimated gender gap in promotion by $7 \%$. Regarding returns to non-cognitive traits, our estimates indicate that a one standard deviation increase in LOC, C-A, or WE leads to a 2-3 percentage points increase in the likelihood of holding a supervisory position or being promoted (5-10\% increase). While not reported in the paper, these findings are similar across countries, sectors, and types of ownership (Appendix Table A3), suggesting that non-cognitive traits, like cognitive abilities, are fairly general and valued not only by a particular market. Consistent with the regression analysis, the results from the Oaxaca-Blinder decomposition indicate that $8-18 \%$ of the gender gap in supervisory status and promotion can be attributed to gender mean-differences in LOC, C-A, and WE. Cognitive abilities appear to be important as well, with a similar proportion of the 
gender gap explained by gender mean-differences in education and self-reported performance. However, only about one-quarter of the gender gap can be attributed to observed mean-differences in our explanatory variables; three-quarters of the gender gap remains unexplained. In fact, nearly all of the unexplained gender gap is driven by difference in the intercept term, the rest of coefficients exhibit little gender difference.

A few limitations in our study restrict our ability to generalize our results. First, although our employer-employee linked data cover a variety of industries and workplaces, we do not have a representative sample in each country nor in each workplace. ${ }^{8}$ Second, our cross-sectional data provide only a snapshot of upward mobility. Panel data that can trace promotions and movements to supervisory positions over a worker's career would provide a more complete picture of the role of noncognitive traits in the dynamics of labor market. Finally, both the OLS regression analysis and Oaxaca-Blinder decomposition focus on the means. A more general distributional approach similar to Pena-Boquete, Stefanis, and Fernandez-Grela (2010) and Russo and Hassink (2012) may provide further insights on gender gap in upward mobility. In particular, as the glass ceiling literature indicates, discrimination against women may be much stronger at the right tail of the distribution - women with highest ability and upward mobility - than the average discrimination. Missing in this literature, however, is a systematic analysis of the extent to which gender differences in upward mobility are explained by a glass ceiling (invisible barrier impeding advance of those electing to pursue upward mobility within an organization), a leaky pipeline (choice to move to another type of employment rather than pursue upward mobility within the organization), or a sticky floor (choice not to pursue upward mobility within an organization).

Our results indicate that there is no single explanation for the gender gap in upward mobility. Similar to the gender wage gap literature, we find that non-cognitive traits provide an important, though incomplete, explanation. Even when controlling for non-cognitive traits and workplace heterogeneity, unknown factors, perhaps discrimination along some unobserved dimensions, or gender differences in other non-

\footnotetext{
${ }^{8}$ Another source of sample selection could be due to gender difference in labor force participation. We are not able to address this issue using our convenient sample as it does not contain people who are no working. However, the gender gaps in labor force participation tend to be relatively small in transition economies because of their high female labor force participation rates. Therefore, the selection bias in this study is probably less severe than other studies in the literature. We thank an anonymous referee for pointing out this problem which is actually largely ignored by the literature.
} 
cognitive traits such as confidence and aspirations, contribute a large proportion of the gender gap in upward mobility. Gender difference in worker characteristics, either gender difference in their means or coefficients, play only a secondary role.

Since our results tend to suggest discrimination remains an important contributing factor, policies addressing the glass ceiling by promoting workplace equality and reducing vertical segregation are probably more effective in terms of closing the gender gap in upward mobility than policies targeting changes in noncognitive traits, as non-cognitive traits tend to be formed relatively early in life and generally remained fixed in adulthood (Cobb-Clark and Schurer 2012). Nevertheless, we find that, regardless of gender, non-cognitive traits significantly increase upward mobility, thus policies addressing this reality cannot be ignored. For example, studies show that men and women start their careers with similar aspirations and confidence, but that both deteriorate earlier and more dramatically for women than for men, which in turn contributes to gender differences in upward mobility (Coffman and Neuenfeldt 2014; Doherty and Manfredi 2006). Indeed, among the employees participating on our survey, $59 \%$ of the males expect to be promoted if they do their job well compared to $43 \%$ of the females. Policies which promote more effective mentoring for women could be used to bolster confidence among qualified female employees considering applying for a supervisory position or promotion. Additionally, time allocation issues associated with additional responsibilities accompanying upward mobility, which tend to work against married women, might be alleviated with policies that provide or subsidize child care. Both types of policies would address the 'sticky floor' component to upward mobility.

\section{References:}

Abdalla, Ikhlas A.H. 1997. "Construct and concurrent validity of three Protestant work ethic measures in an Arabian Gulf society." Journal of Managerial Psychology no. 12 (4):251-260. doi: doi:10.1108/02683949710174856.

Ali, Abbas J, Thomas Falcone, and Ahmed A Azim. 1995. "Work ethic in the USA and Canada." Journal of Management Development no. 14 (6):26-34.

Berings, Dries, Filip De Fruyt, and René Bouwen. 2004. "Work values and personality traits as predictors of enterprising and social vocational interests." Personality and Individual Differences no. $36 \quad(2): 349-364 . \quad$ doi: http://dx.doi.org/10.1016/S0191-8869(03)00101-6. 
Blau, Francine D., and Jed DeVaro. 2007. "New evidence on gender differences in promotion rates: an empirical analysis of a sample of new hires." Industrial Relations: A Journal of Economy and Society no. 46 (3):511-550. doi: 10.1111/j.1468-232X.2007.00479.x.

Blood, Milton R. 1969. "Work values and job satisfaction." Journal of Applied Psychology no. 53 (6):456.

Boatwright, John, and John Slate. 2000. "Work ethic measurement of vocational students in Georgia." Journal of Vocational Education Research no. 25 (4):503531.

Bonnett, Celia, and Adrian Furnham. 1991. "Who wants to be an entrepreneur? A study of adolescents interested in a Young Enterprise scheme." Journal of Economic Psychology no. 12 (3):465-478. doi: http://dx.doi.org/10.1016/01674870(91)90027-Q.

Cebi, Merve. 2007. "Locus of control and human capital investment revisited." The Journal of Human Resources no. 42 (4):919-932. doi: 10.2307/40057334.

Cobb-Clark, Deborah A., and Stefanie Schurer. 2012. "The stability of Big-Five personality traits." Economics Letters no. 115 (1):11-15. doi: http://dx.doi.org/10.1016/j.econlet.2011.11.015.

Cobb-Clark, Deborah A., and Michelle Tan. 2011. "Noncognitive skills, occupational attainment, and relative wages." Labour Economics no. 18 (1):1-13. doi: http://dx.doi.org/10.1016/j.labeco.2010.07.003.

Cobb-Clark, DeborahA. 2015. "Locus of control and the labor market." IZA Journal of Labor Economics no. 4 (1):1-19. doi: 10.1186/s40172-014-0017-x.

Coffman, Julie, and William Neuenfeldt. 2014. "Everyday moments in truth: frontline managers are key to women's career aspirations." Bain \& Company, Inc.

Doherty, Liz, and Simonetta Manfredi. 2006. "Women's progression to senior positions in English universities." Employee Relations no. 28 (6):553-572. doi: doi:10.1108/01425450610704498.

Duncan, Greg J., and Rachel Dunifon. 2012. "“Soft-skills" and long-run labor market success." In 35th Anniversary Retrospective (Research in Labor Economics, Volume 35) edited by Solomon W. Polachek and Konstantinos Tatsiramos, 313339. Emerald Group Publishing Limited.

Dunifon, Rachel, and Greg J. Duncan. 1998. "Long-run effects of motivation on labormarket success." Social Psychology Quarterly no. 61 (1):33-48. doi: $10.2307 / 2787056$. 
Elder, Todd, John H. Goddeeris, and Steven J. Haider. 2010. "Unexplained gaps and Oaxaca-Blinder decompositions." Labour Economics no. 17:284-290.

Fortin, Nicole M. 2008. "The Gender wage gap among young adults in the United States: The importance of money versus people." Journal of Human Resources no. 43 (4):884-918. doi: 10.3368/jhr.43.4.884.

Furnham, Adrian. 1990. "A content, correlational, and factor analytic study of seven questionnaire measures of the Protestant work ethic." Human Relations no. 43 (4):383-399. doi: 10.1177/001872679004300406.

Ghorpade, Jai, Jim Lackritz, and Gangaram Singh. 2006. "Correlates of the Protestant ethic of hard work: results from a diverse ethno-religious sample." Journal of Applied Social Psychology no. 36 (10):2449-2473.

Grove, Wayne A., Andrew Hussey, and Michael Jetter. 2011. "The gender pay gap beyond human capital: heterogeneity in noncognitive skills and in labor market tastes." Journal of Human Resources no. 46 (4):827-874.

Jann, Ben. 2008. "The Blinder-Oaxaca decomposition for linear regression models." The Stata Journal 8(4), no. 8 (4):453-479.

Johnston, David W., and Wang-Sheng Lee. 2012. "Climbing the job ladder: new evidence of gender inequity." Industrial Relations: A Journal of Economy and Society no. 51 (1):129-151. doi: 10.1111/j.1468-232X.2011.00667.x.

Judge, Timothy A, Joyce E Bono, and Edwin A Locke. 2000. "Personality and job satisfaction: the mediating role of job characteristics." Journal of applied psychology no. 85 (2):237.

Judge, Timothy A., and Joyce E. Bono. 2001. "Relationship of core self-evaluations traits-self-esteem, generalized self-efficacy, locus of control, and emotional stability — with job satisfaction and job performance: A meta-analysis." Journal of Applied Psychology no. 86 (1):80-92. doi: 10.1037/0021-9010.86.1.80.

Kirkcaldy, Bruce D., Adrian Furnham, and Richard Lynn. 1992. "Individual differences in work attitudes." Personality and Individual Differences no. 13 (1):49-55. doi: http://dx.doi.org/10.1016/0191-8869(92)90217-D.

Lee, Kibeom, Julie J. Carswell, and Natalie J. Allen. 2000. "A meta-analytic review of occupational commitment: Relations with person- and work-related variables." Journal of Applied Psychology no. 85 (5):799-811. doi: 10.1037/00219010.85.5.799.

Linz, Susan J., and Anastasia Semykina. 2009. "Personality traits as performance enhancers? A comparative analysis of workers in Russia, Armenia and 
Kazakhstan." Journal of Economic Psychology no. 30 (1):71-91. doi: 10.1016/j.joep.2008.08.009.

2011. "Personality and performance: A comparative analysis of workers in transition economies." Personality and Individual Differences no. 51 (3):293301. doi: http://dx.doi.org/10.1016/j.paid.2010.04.019.

Mann, Melissa Janine. 2010. “A quantitative and qualitative analysis identifying antecedents of work ethic beliefs and the relationship between work ethic beliefs and in-role and extra-role work behavior: New work ethic dimensions and scale introduced." State University of New York at Albany.

Manning, Alan, and Joanna Swaffield. 2008. "The gender gap in early-career wage growth." The Economic Journal no. 118 (530):983-1024. doi: 10.1111/j.14680297.2008.02158.x.

Meriac, John P., Taylor L. Poling, and David J. Woehr. 2009. "Are there gender differences in work ethic? An examination of the measurement equivalence of the multidimensional work ethic profile." Personality and Individual Differences no. 47 (3):209-213. doi: 10.1016/j.paid.2009.03.001.

Miller, Michael J., David J. Woehr, and Natasha Hudspeth. 2002. "The meaning and measurement of work ethic: construction and initial validation of a multidimensional inventory." Journal of Vocational Behavior no. 60 (3):451489.

Mueller, Gerrit, and Erik Plug. 2006. "Estimating the effect of personality on male and female earnings." Industrial \& Labor Relations Review no. 60 (1):3-22. doi: 10.1177/001979390606000101.

Ng, Thomas W. H., Kelly L. Sorensen, and Lillian T. Eby. 2006. "Locus of control at work: a meta-analysis." Journal of Organizational Behavior no. 27 (8):10571087. doi: 10.1002/job.416.

Pekkarinen, Tuomas, and Juhana Vartiainen. 2006. "Gender differences in promotion on a job ladder: evidence from Finnish metalworkers." Industrial and Labor Relations Review no. 59 (2):285-301. doi: 10.2307/25067521.

Pena-Boquete, Yolanda, Sergio De Stefanis, and Manuel Fernandez-Grela. 2010. "The distribution of gender wage discrimination in Italy and Spain: a comparison using the ECHP." International Journal of Manpower no. 31 (2):109-137. doi: doi:10.1108/01437721011042232.

Rotter, Julian B. 1966. "Generalized expectancies for internal versus external control of reinforcement." Psychological monographs: General and applied no. 80 (1): 1 . 
Rowe, Reba, and William E. Snizek. 1995. "Gender differences in work values: perpetuating the myth." Work and Occupations no. 22 (2):215-229. doi: $10.1177 / 0730888495022002005$.

Russo, Giovanni, and Wolter Hassink. 2012. "Multiple glass ceilings." Industrial Relations: A Journal of Economy and Society no. 51 (4):892-915. doi: 10.1111/j.1468-232X.2012.00705.x.

Semykina, Anastasia, and Susan J. Linz. 2007. "Gender differences in personality and earnings: Evidence from Russia." Journal of Economic Psychology no. 28 (3):387-410. doi: 10.1016/j.joep.2006.05.004.

2010. "Analyzing the gender pay gap in transition economies: How much does personality matter?" Human Relations. doi: 10.1177/0018726709339094.

Sherman, Adrian C., Graham E. Higgs, and Robert L. Williams. 1997. "Gender differences in the locus of control construct." Psychology \& Health no. 12 (2):239-248. doi: 10.1080/08870449708407402.

Thornton, Grant. 2015. Women in business: the path to leadership. In Grant Thornton International Business Report 2015: Grant Thornton International Ltd.

Vansteenkiste, Maarten, Bart Neyrinck, Christopher P. Niemiec, Bart Soenens, Hans De Witte, and Anja Van den Broeck. 2007. "On the relations among work value orientations, psychological need satisfaction and job outcomes: A selfdetermination theory approach." Journal of Occupational and Organizational Psychology no. 80 (2):251-277. doi: 10.1348/096317906X111024.

Wang, Qiang, Nathan A Bowling, and Kevin J Eschleman. 2010. "A meta-analytic examination of work and general locus of control." Journal of Applied Psychology no. 95 (4):761.

Wentworth, Diane Keyser, and Robert M Chell. 1997. "American college students and the Protestant work ethic." The Journal of Social Psychology no. 137 (3):284296.

Yousef, Darwish A. 2001. "Islamic work ethic - A moderator between organizational commitment and job satisfaction in a cross-cultural context." Personnel Review no. 30 (2):152-169. doi: doi:10.1108/00483480110380325. 
Table 1: Sample Characteristics

\begin{tabular}{lcccl}
\hline & $(1)$ & $(2)$ & $(3)$ & $\begin{array}{l}(4) \\
\text { Gender } \\
\text { Difference }\end{array}$ \\
\cline { 2 - 5 } Worker Characteristics & & & & \\
& & & & \\
Female & 0.573 & & & \\
& $(0.495)$ & & & \\
Married & 0.543 & 0.587 & 0.510 & $0.078^{* * *}$ \\
& $(0.498)$ & $(0.492)$ & $(0.500)$ & $(0.012)$ \\
Age (at time of interview) & 36.65 & 36.39 & 36.85 & $-0.451^{*}$ \\
& $(11.07)$ & $(10.85)$ & $(11.12)$ & $(0.257)$ \\
Years of Schooling & 14.56 & 14.53 & 14.58 & -0.042 \\
Job Tenure (years at current & $(2.75)$ & $(2.74)$ & $(2.76)$ & $(0.064)$ \\
workplace) & 7.225 & 6.226 & 7.970 & $-1.744^{* * *}$ \\
& $(7.710)$ & $(6.560)$ & $(8.371)$ & $(0.179)$ \\
Holding Multi-jobs & 0.125 & 0.148 & 0.108 & $0.040^{* * *}$ \\
Unemployment Experience & $(0.330)$ & $(0.355)$ & $(0.310)$ & $(0.008)$ \\
(in the past 5 years) & 0.337 & 0.335 & 0.339 & -0.003 \\
& $(0.474)$ & $(0.472)$ & $(0.473)$ & $(0.011)$ \\
Performance & 10.56 & 10.67 & 10.48 & $0.186^{* * * *}$ \\
Being a Supervisor & $(1.74)$ & $(1.76)$ & $(1.72)$ & $(0.041)$ \\
Ever Receiving Promotions & 0.333 & 0.382 & 0.295 & $0.086^{* * *}$ \\
(from current workplace) & $(0.471)$ & $(0.486)$ & $(0.456)$ & $(0.011)$ \\
& 0.484 & 0.489 & 0.480 & 0.010 \\
& $(0.500)$ & $(0.500)$ & $(0.500)$ & $(0.012)$ \\
& & & &
\end{tabular}

Workplace Characteristics (\%)

State-owned organization

$\begin{array}{llll}43.8 & 37.7 & 48.4 & -10.7\end{array}$

Manufacturing

29.0

21.6

7.3

Education/health care

19.0

14.2

22.6

$-8.4$

Retail and other services

22.4

18.7

25.2

$-6.5$

Finance organization

5.8

6.9

5.0

1.9

Public sector (local, region, federal)

22.8

23.4

22.3

1.0

Construction/transportation

5.1

7.8

3.2

4.6

Obs.

7,502

3,206

4,296

Note. $* * * \mathrm{p}<0.01, * * \mathrm{p}<0.05, * \mathrm{p}<0.1$. 


\section{Internal LOC}

Success comes from hard work, not

luck

People get the respect they deserved

I can make my plans work

I control what happens to me

Getting what I want has little to do with luck

\begin{tabular}{|c|c|c|c|}
\hline Pool & Male & Female & $\begin{array}{l}\text { Gender } \\
\text { Difference }\end{array}$ \\
\hline $\begin{array}{c}3.46 \\
(1.24)\end{array}$ & $\begin{array}{c}3.53 \\
(1.21)\end{array}$ & $\begin{array}{c}3.40 \\
(1.26)\end{array}$ & $\begin{array}{l}0.134 * * * \\
(0.029)\end{array}$ \\
\hline $\begin{array}{c}3.72 \\
(1.16)\end{array}$ & $\begin{array}{c}3.72 \\
(1.15)\end{array}$ & $\begin{array}{c}3.73 \\
(1.18)\end{array}$ & $\begin{array}{l}-0.023 \\
(0.027)\end{array}$ \\
\hline $\begin{array}{c}3.69 \\
(1.02)\end{array}$ & $\begin{array}{c}3.74 \\
(0.98)\end{array}$ & $\begin{array}{c}3.65 \\
(1.04)\end{array}$ & $\begin{array}{l}0.087 * * * \\
(0.024)\end{array}$ \\
\hline $\begin{array}{c}3.72 \\
(1.11)\end{array}$ & $\begin{array}{c}3.80 \\
(1.07)\end{array}$ & $\begin{array}{c}3.66 \\
(1.14)\end{array}$ & $\begin{array}{l}0.135^{* * *} * \\
(0.026)\end{array}$ \\
\hline $\begin{array}{c}3.38 \\
(1.14)\end{array}$ & $\begin{array}{c}3.38 \\
(1.13)\end{array}$ & $\begin{array}{c}3.37 \\
(1.15)\end{array}$ & $\begin{array}{l}0.022 \\
(0.027)\end{array}$ \\
\hline
\end{tabular}

\section{External LOC}

Without right breaks, cannot be good leader

$\begin{array}{cccc}3.68 & 3.66 & 3.70 & -0.037 \\ (1.14) & (1.14) & (1.14) & (0.027)\end{array}$

Unhappy outcomes caused by bad luck

\subsection{9}

3.21

3.18

0.034

(1.18)

(0.028)

Promotions depend on luck

Life is controlled by accidents

I have no influence over things that

$\begin{array}{lcccl}\text { LOC } & 1.171 & 1.521 & 0.910 & 0.612^{* * *} \\ & (5.121) & (4.998) & (5.196) & (0.119) \\ \text { Re-scaled LOC } & 0.529 & 0.538 & 0.522 & 0.015^{* * *} \\ & (0.128) & (0.124) & (0.130) & (0.003)\end{array}$

\section{Cronbach's alpha}

$0.60 \quad 0.61$

0.59

Obs.

7,502

3,206

4,296

Note. Means are derived using 5-point scale where: $1=$ strongly disagree; $5=$ strongly agree. Standard deviations are in parentheses. The re-scaled LOC measure is within the unit interval and from the formula: (internal-external +20$) / 40$. 


\section{Challenge}

It is important to receive a promotion

It is important to accomplish

something worthwhile

\begin{tabular}{|c|c|c|c|}
\hline Pool & Male & Female & $\begin{array}{l}\text { Gender } \\
\text { Difference }\end{array}$ \\
\hline $\begin{array}{c}4.13 \\
(1.07)\end{array}$ & $\begin{array}{c}4.13 \\
(1.08)\end{array}$ & $\begin{array}{c}4.12 \\
(1.05)\end{array}$ & $\begin{array}{l}0.009 \\
(0.025)\end{array}$ \\
\hline $\begin{array}{c}4.14 \\
(1.08)\end{array}$ & $\begin{array}{c}4.22 \\
(1.04)\end{array}$ & $\begin{array}{c}4.03 \\
(1.12)\end{array}$ & $\begin{array}{l}0.192 * * * \\
(0.025)\end{array}$ \\
\hline
\end{tabular}

\section{Affiliation}

It is important to receive the respect

$\begin{array}{cccl}4.44 & 4.50 & 4.36 & 0.136 * * * \\ (0.82) & (0.79) & (0.86) & (0.019) \\ 4.45 & 4.52 & 4.36 & 0.167 * * * \\ (0.79) & (0.77) & (0.81) & (0.018)\end{array}$

C-A

$\begin{array}{llll}-0.627 & -0.569 & -0.671 & 0.102 * *\end{array}$

from co-workers

(2.018)

(2.044)

(1.998)

(0.047)

Re-scaled C-A

0.461

0.464

0.458

$0.006 * *$

(0.126)

$(0.128)$

(0.125)

(0.003)

\section{Cronbach's alpha}

$\begin{array}{ll}0.63 & 0.61\end{array}$

0.63

Obs.

7,502

3,206

4,296

Note. Means are derived using 5-point scale where: $1=$ strongly disagree; $5=$ strongly agree. Standard deviations are in parentheses. The re-scaled C-A measure is within the unit interval from the formula: (challenge - affiliation +8 )/16 


\begin{tabular}{|c|c|c|c|c|}
\hline & Pool & Male & Female & $\begin{array}{l}\text { Gender } \\
\text { Difference }\end{array}$ \\
\hline \multicolumn{5}{|l|}{ Positively-worded statements } \\
\hline Hard work makes on a better person & $\begin{array}{l}3.17 \\
(1.44)\end{array}$ & $\begin{array}{c}3.41 \\
(1.35)\end{array}$ & $\begin{array}{c}2.99 \\
(1.48)\end{array}$ & $\begin{array}{l}0.413 * * * \\
(0.033)\end{array}$ \\
\hline $\begin{array}{l}\text { Wasting time is as bad as wasting } \\
\text { money }\end{array}$ & $\begin{array}{c}4.14 \\
(1.06)\end{array}$ & $\begin{array}{c}4.11 \\
(1.05)\end{array}$ & $\begin{array}{c}4.16 \\
(1.06)\end{array}$ & $\begin{array}{l}-0.044^{*} \\
(0.025)\end{array}$ \\
\hline $\begin{array}{l}\text { A good indication of a person's worth } \\
\text { is how well his/her job is done }\end{array}$ & $\begin{array}{c}3.80 \\
(1.06)\end{array}$ & $\begin{array}{c}3.82 \\
(1.03)\end{array}$ & $\begin{array}{c}3.77 \\
(1.09)\end{array}$ & $\begin{array}{l}0.049 * * \\
(0.025)\end{array}$ \\
\hline $\begin{array}{l}\text { If all other things are equal, it is better } \\
\text { to have a job with a lot of } \\
\text { responsibility than one with little } \\
\text { responsibility }\end{array}$ & $\begin{array}{c}3.40 \\
(1.21)\end{array}$ & $\begin{array}{c}3.40 \\
(1.23)\end{array}$ & $\begin{array}{c}3.40 \\
(1.19)\end{array}$ & $\begin{array}{l}-0.004 \\
(0.028)\end{array}$ \\
\hline \multicolumn{5}{|l|}{ Negatively-worded statements } \\
\hline $\begin{array}{l}\text { When the work day is finished, a } \\
\text { person should forget his/her job and } \\
\text { enjoy himself/herself }\end{array}$ & $\begin{array}{c}4.07 \\
(1.14)\end{array}$ & $\begin{array}{c}3.96 \\
(1.18)\end{array}$ & $\begin{array}{c}4.16 \\
(1.11)\end{array}$ & $\begin{array}{l}-0.195 * * * \\
(0.027)\end{array}$ \\
\hline $\begin{array}{l}\text { The principal purpose of a person's job } \\
\text { it to provide a means for enjoying free } \\
\text { time }\end{array}$ & $\begin{array}{c}3.83 \\
(1.13)\end{array}$ & $\begin{array}{c}3.80 \\
(1.13)\end{array}$ & $\begin{array}{c}3.86 \\
(1.13)\end{array}$ & $\begin{array}{l}-0.056 * * \\
(0.026)\end{array}$ \\
\hline $\begin{array}{l}\text { Whenever possible, a person should } \\
\text { relax and accept life as it is, rather than } \\
\text { always striving for unreachable goals }\end{array}$ & $\begin{array}{c}3.52 \\
(1.33)\end{array}$ & $\begin{array}{c}3.42 \\
(1.36)\end{array}$ & $\begin{array}{c}3.59 \\
(1.30)\end{array}$ & $\begin{array}{l}-0.175^{* * * *} \\
(0.031)\end{array}$ \\
\hline $\begin{array}{l}\text { People who 'do things the easy way' } \\
\text { are the smart one }\end{array}$ & $\begin{array}{l}3.17 \\
(1.37)\end{array}$ & $\begin{array}{c}3.27 \\
(1.34)\end{array}$ & $\begin{array}{c}3.10 \\
(1.39)\end{array}$ & $\begin{array}{l}-0.056 * * \\
(0.026)\end{array}$ \\
\hline WE & $\begin{array}{l}-0.092 \\
(3.684)\end{array}$ & $\begin{array}{c}0.289 \\
(3.673)\end{array}$ & $\begin{array}{l}-0.376 \\
(3.667)\end{array}$ & $\begin{array}{l}0.664 * * * \\
(0.086)\end{array}$ \\
\hline Re-scaled WE & $\begin{array}{c}0.497 \\
(0.115)\end{array}$ & $\begin{array}{c}0.509 \\
(0.115)\end{array}$ & $\begin{array}{c}0.488 \\
(0.115)\end{array}$ & $\begin{array}{l}0.021 * * * \\
(0.003)\end{array}$ \\
\hline Cronbach's alpha & 0.50 & 0.50 & 0.50 & \\
\hline Obs. & 7,502 & 3,206 & 4,296 & \\
\hline
\end{tabular}

Note. Means are derived using 5-point scale where: $1=$ strongly disagree; $5=$ strongly agree. Standard deviations are in parentheses. The re-scaled WE measure is within the unit interval from the formula: (positive - negative +16 )/32 
Table 5: Effects of Non-Cognitive Traits on Supervisory Status and Promotion

\begin{tabular}{|c|c|c|c|c|}
\hline \multirow{3}{*}{ Female } & \multirow{2}{*}{\multicolumn{2}{|c|}{$\begin{array}{c}(2) \\
\text { Supervisor }\end{array}$}} & \multirow{2}{*}{\multicolumn{2}{|c|}{$\begin{array}{c}(4) \\
\text { Promotion }\end{array}$}} \\
\hline & & & & \\
\hline & $\begin{array}{l}-10.10 * * * \\
(1.48)\end{array}$ & $\begin{array}{l}-9.30 * * * \\
(1.44)\end{array}$ & $\begin{array}{l}-3.32 * * \\
(1.53)\end{array}$ & $\begin{array}{l}-2.76^{*} \\
(1.52)\end{array}$ \\
\hline Married & $\begin{array}{l}5.95^{* * *} \\
(1.21)\end{array}$ & $\begin{array}{l}5.68 * * * \\
(1.20)\end{array}$ & $\begin{array}{l}2.10^{*} \\
(1.23)\end{array}$ & $\begin{array}{l}2.00 \\
(1.22)\end{array}$ \\
\hline Age & $\begin{array}{l}1.59 * * * \\
(0.42)\end{array}$ & $\begin{array}{l}1.70 * * * \\
(0.41)\end{array}$ & $\begin{array}{l}0.63 \\
(0.45)\end{array}$ & $\begin{array}{l}0.69 \\
(0.45)\end{array}$ \\
\hline Age Squared & $\begin{array}{l}-0.01 * * \\
(0.01)\end{array}$ & $\begin{array}{l}-0.01 * * \\
(0.01)\end{array}$ & $\begin{array}{l}-0.01 \\
(0.01)\end{array}$ & $\begin{array}{l}-0.01 \\
(0.01)\end{array}$ \\
\hline Job Tenure & $\begin{array}{l}2.06 * * * \\
(0.34)\end{array}$ & $\begin{array}{l}2.12 * * * \\
(0.34)\end{array}$ & $\begin{array}{l}3.86 * * * \\
(0.39)\end{array}$ & $\begin{array}{l}3.90 * * * \\
(0.39)\end{array}$ \\
\hline Job Tenure Squared & $\begin{array}{l}-0.05^{* * * *} \\
(0.01)\end{array}$ & $\begin{array}{l}-0.05 * * * \\
(0.01)\end{array}$ & $\begin{array}{l}-0.07 * * * \\
(0.01)\end{array}$ & $\begin{array}{l}-0.07 * * * \\
(0.01)\end{array}$ \\
\hline Unemployment & $\begin{array}{l}-4.59 * * * \\
(1.48)\end{array}$ & $\begin{array}{l}-4.45 * * * \\
(1.46)\end{array}$ & $\begin{array}{l}-4.97 * * * \\
(1.59)\end{array}$ & $\begin{array}{l}-4.93 * * * \\
(1.60)\end{array}$ \\
\hline Holding Multi-jobs & $\begin{array}{l}3.93 * * \\
(1.83)\end{array}$ & $\begin{array}{l}3.70 * * \\
(1.80)\end{array}$ & $\begin{array}{l}4.12 * * \\
(1.97)\end{array}$ & $\begin{array}{l}3.97 * * \\
(1.94)\end{array}$ \\
\hline Years of Schooling & $\begin{array}{l}2.12 * * * \\
(0.34)\end{array}$ & $\begin{array}{l}1.95 * * * \\
(0.33)\end{array}$ & $\begin{array}{l}2.07 * * * \\
(0.28)\end{array}$ & $\begin{array}{l}1.95 * * * \\
(0.28)\end{array}$ \\
\hline Performance & $\begin{array}{l}50.00 * * * \\
(4.53)\end{array}$ & $\begin{array}{l}45.81 * * * \\
(4.43)\end{array}$ & $\begin{array}{l}37.17 * * * \\
(4.64)\end{array}$ & $\begin{array}{l}34.02 * * * \\
(4.58)\end{array}$ \\
\hline Locus of Control & & $\begin{array}{l}16.49 * * * \\
(4.83)\end{array}$ & & $\begin{array}{l}7.62 \\
(5.18)\end{array}$ \\
\hline $\mathrm{C}-\mathrm{A}$ & & $\begin{array}{l}18.63^{* * *} \\
(4.61)\end{array}$ & & $\begin{array}{l}23.39 * * * \\
(5.21)\end{array}$ \\
\hline Work Ethic & & $\begin{array}{l}28.09 * * * \\
(5.38)\end{array}$ & & $\begin{array}{l}13.39 * * \\
(5.71)\end{array}$ \\
\hline Obs. & 7,460 & 7,460 & 7,502 & 7,502 \\
\hline R-squared & 0.28 & 0.28 & 0.28 & 0.28 \\
\hline
\end{tabular}

Note. All regressions include workplace fixed effects. The estimates are multiplied by 100 and can be interpreted as percentage points. Robust standard errors are reported in parentheses, and they are clustered at the workplace level. $* * * \mathrm{p}<0.01, * * \mathrm{p}<0.05$, * $\mathrm{p}<0.1$ 
Table 6: Effects of Non-Cognitive Traits

\begin{tabular}{|c|c|c|}
\hline & $\begin{array}{l}\text { (1) } \\
\text { Supervisor }\end{array}$ & $\begin{array}{l}(2) \\
\text { Promotion }\end{array}$ \\
\hline Female & $\begin{array}{l}-9.50 * * * \\
(1.42)\end{array}$ & $\begin{array}{l}-3.10^{* *} \\
(1.52)\end{array}$ \\
\hline Married & $\begin{array}{l}5.59 * * * \\
(1.20)\end{array}$ & $\begin{array}{l}1.96 \\
(1.22)\end{array}$ \\
\hline Age & $\begin{array}{l}1.75 * * * \\
(0.41)\end{array}$ & $\begin{array}{l}0.72 \\
(0.44)\end{array}$ \\
\hline Age Squared & $\begin{array}{l}-0.01 * * * \\
(0.00)\end{array}$ & $\begin{array}{l}-0.01^{*} \\
(0.01)\end{array}$ \\
\hline Job Tenure & $\begin{array}{l}2.12 * * * \\
(0.34)\end{array}$ & $\begin{array}{l}3.90 * * * \\
(0.38)\end{array}$ \\
\hline Job Tenure Squared & $\begin{array}{l}-0.05 * * * \\
(0.01)\end{array}$ & $\begin{array}{l}-0.07 * * * \\
(0.01)\end{array}$ \\
\hline Unemployment & $\begin{array}{l}-4.51 * * * \\
(1.47)\end{array}$ & $\begin{array}{l}-4.97 * * * \\
(1.60)\end{array}$ \\
\hline Holding Multi-jobs & $\begin{array}{l}3.95 * * \\
(1.80)\end{array}$ & $\begin{array}{l}4.35^{* *} \\
(1.94)\end{array}$ \\
\hline Years of Schooling & $\begin{array}{l}1.93 * * * \\
(0.33)\end{array}$ & $\begin{array}{l}1.92 * * * \\
(0.28)\end{array}$ \\
\hline $\begin{array}{c}\text { Anticipate and Prevent } \\
\text { Problem }\end{array}$ & $\begin{array}{l}21.62 * * * \\
(3.83)\end{array}$ & $\begin{array}{l}7.44 * \\
(4.06)\end{array}$ \\
\hline Quality of Work Performance & $\begin{array}{l}15.81 * * * \\
(3.76)\end{array}$ & $\begin{array}{l}18.74 * * * \\
(3.48)\end{array}$ \\
\hline Productivity & $\begin{array}{l}7.98^{*} \\
(4.08)\end{array}$ & $\begin{array}{l}5.61 \\
(4.38)\end{array}$ \\
\hline Internal Locus of Control & $\begin{array}{l}8.75 * * \\
(3.75)\end{array}$ & $\begin{array}{l}5.85 \\
(3.82)\end{array}$ \\
\hline External Locus of Control & $\begin{array}{l}-7.58 * * \\
(3.41)\end{array}$ & $\begin{array}{l}-1.31 \\
(3.61)\end{array}$ \\
\hline Preference for Challenge & $\begin{array}{l}15.31 * * * \\
(2.94)\end{array}$ & $\begin{array}{l}19.94 * * * \\
(3.21)\end{array}$ \\
\hline Preference for Affiliation & $\begin{array}{l}-0.23 \\
(3.07)\end{array}$ & $\begin{array}{l}1.05 \\
(3.50)\end{array}$ \\
\hline Positive Work Ethic & $\begin{array}{l}14.14 * * * \\
(3.66)\end{array}$ & $\begin{array}{l}5.54 \\
(4.10)\end{array}$ \\
\hline Negative Work Ethic & $\begin{array}{l}-12.46^{* * * *} \\
(3.69)\end{array}$ & $\begin{array}{l}-5.62 \\
(3.50)\end{array}$ \\
\hline $\begin{array}{c}\text { Obs. } \\
\text { R-squared }\end{array}$ & $\begin{array}{l}7,460 \\
0.29\end{array}$ & $\begin{array}{l}7,502 \\
0.29\end{array}$ \\
\hline \multicolumn{3}{|c|}{$\begin{array}{l}\text { Note. All regressions include workplace fixed effects. The } \\
\text { estimates are multiplied by } 100 \text { and can be interpreted as } \\
\text { percentage points. Robust standard errors are reported in } \\
\text { parentheses, and they are clustered at the workplace level. *** } \\
\mathrm{p}<0.01, * * \mathrm{p}<0.05, * \mathrm{p}<0.1\end{array}$} \\
\hline
\end{tabular}

Table 7: Oaxaca-Blinder Decomposition on Supervisory Status 


\begin{tabular}{|c|c|c|c|}
\hline & $\begin{array}{l}\text { Total Gender } \\
\text { Difference }\end{array}$ & $\begin{array}{l}\text { "Explained" } \\
\text { Difference in } \\
\text { Characteristics }\end{array}$ & $\begin{array}{l}\text { "Unexplained" } \\
\text { Difference in } \\
\text { Coefficients }\end{array}$ \\
\hline w/o non-cognitive factors & $\begin{array}{l}8.69 * * * \\
(1.11)\end{array}$ & $\begin{array}{l}1.32 * * * \\
(0.44)\end{array}$ & $\begin{array}{l}7.37 * * * \\
(1.06)\end{array}$ \\
\hline w/ non-cognitive factors & $\begin{array}{l}8.69 * * * \\
(1.11)\end{array}$ & $\begin{array}{l}1.91 * * * \\
(0.47)\end{array}$ & $\begin{array}{l}6.78 * * * \\
(1.03)\end{array}$ \\
\hline
\end{tabular}

\section{Each Component}

\begin{tabular}{|c|c|c|}
\hline Married & $\begin{array}{l}0.37 * * * \\
(0.09)\end{array}$ & $\begin{array}{l}0.07 * * \\
(0.03)\end{array}$ \\
\hline Age & $\begin{array}{l}0.56 \\
(0.43)\end{array}$ & $\begin{array}{l}0.09 \\
(0.09)\end{array}$ \\
\hline Age Squared & $\begin{array}{l}-0.37 \\
(0.28)\end{array}$ & $\begin{array}{l}-0.09 \\
(0.09)\end{array}$ \\
\hline Job Tenure & $\begin{array}{l}-1.06 * * * \\
(0.39)\end{array}$ & $\begin{array}{l}-0.01 \\
(0.03)\end{array}$ \\
\hline Job Tenure Squared & $\begin{array}{l}0.84 * * * \\
(0.30)\end{array}$ & $\begin{array}{l}-0.00 \\
(0.04)\end{array}$ \\
\hline Unemployment & $\begin{array}{l}0.02 \\
(0.04)\end{array}$ & $\begin{array}{l}0.00 \\
(0.00)\end{array}$ \\
\hline Holding Multi-jobs & $\begin{array}{l}0.17 * * \\
(0.08)\end{array}$ & $\begin{array}{l}0.00 \\
(0.02)\end{array}$ \\
\hline Years of Schooling & $\begin{array}{l}0.47 * * * \\
(0.14)\end{array}$ & $\begin{array}{l}0.05^{*} \\
(0.03)\end{array}$ \\
\hline Performance & $\begin{array}{l}0.24 \\
(0.16)\end{array}$ & $\begin{array}{l}0.00 \\
(0.01)\end{array}$ \\
\hline Locus of Control & $\begin{array}{l}0.30 * * * \\
(0.10)\end{array}$ & $\begin{array}{l}0.00 \\
(0.03)\end{array}$ \\
\hline $\mathrm{C}-\mathrm{A}$ & $\begin{array}{l}0.18^{* * * *} \\
(0.07)\end{array}$ & $\begin{array}{l}-0.02 \\
(0.01)\end{array}$ \\
\hline Work Ethic & $\begin{array}{l}0.20 * * * \\
(0.07)\end{array}$ & $\begin{array}{l}0.00 \\
(0.01)\end{array}$ \\
\hline Intercept & & $\begin{array}{l}6.68 * * * \\
(1.02)\end{array}$ \\
\hline
\end{tabular}

Note. The Oaxaca-Blinder decomposition estimates are from the residuals of the dependent and explanatory variables that partial out workplace fixed effects. The estimates are multiplied by 100 and can be interpreted as percentage points. Robust standard errors are reported in parentheses, and they are clustered at the workplace level. $* * * \mathrm{p}<0.01, * * \mathrm{p}<0.05, * \mathrm{p}<0.1$ 


\begin{tabular}{llll}
\hline & $(1)$ & $(2)$ & $(3)$ \\
& $\begin{array}{l}\text { Total Gender } \\
\text { Difference }\end{array}$ & $\begin{array}{l}\text { "Explained" } \\
\text { Difference in } \\
\text { Characteristics }\end{array}$ & $\begin{array}{l}\text { "Unexplained" } \\
\text { Difference in } \\
\text { Coefficients }\end{array}$ \\
\cline { 2 - 4 } w/o non-cognitive factors & $2.64^{* *}$ & 0.25 & $2.39^{* *}$ \\
& $(1.14)$ & $(0.41)$ & $(1.08)$ \\
w/ non-cognitive factors & $2.64^{* *}$ & 0.67 & $1.97 *$ \\
& $(1.14)$ & $(0.43)$ & $(1.06)$
\end{tabular}

\section{Each Component}

Married

$0.13^{*} \quad 0.04$

(0.08) (0.03)

Age

$0.26 \quad 0.02$

Age Squared

(0.23) (0.05)

$-0.28 \quad-0.03$

$(0.24) \quad(0.05)$

Job Tenure

$-1.92 * * * \quad 0.02$

(0.67) (0.05)

Job Tenure Squared

$1.20 * * * \quad-0.02$

(0.41) (0.06)

Unemployment

$0.01 \quad-0.01$

(0.05) (0.01)

$0.17 * * \quad-0.01$

Holding Multi-jobs

(0.08) (0.01)

Years of Schooling

$0.45 * * * \quad 0.05$

(0.13) (0.03)

Performance

$0.17 \quad 0.01$

$(0.12) \quad(0.01)$

Locus of Control

$0.13 \quad 0.03$

(0.09) (0.03)

C-A

$0.25^{* * *} \quad-0.00$

(0.08) (0.01)

Work Ethic

$0.10 * * \quad 0.00$

$(0.05) \quad(0.01)$

Intercept

Note. The Oaxaca-Blinder decomposition estimates are from residuals of the dependent and explanatory variables that partial out workplace fixed effects. The estimates are multiplied by 100 and can be interpreted as percentage points. Robust standard errors are reported in parentheses, and they are clustered at the workplace level. $* * * \mathrm{p}<0.01, * * \mathrm{p}<0.05, * \mathrm{p}<0.1$ 


Pool Male Female $\begin{gathered}\text { Gender } \\ \text { Difference }\end{gathered}$

\section{Compared to others doing the same work}

How well do you anticipate problems that may arise and try to prevent them or minimize their effects?

The overall quality of my work performance is

$\begin{array}{cccl}3.53 & 3.59 & 3.48 & 0.107 * * * \\ (0.69) & (0.70) & (0.67) & (0.016) \\ & & & \\ 3.53 & 3.56 & 3.51 & 0.050 * * * \\ (0.74) & (0.75) & (0.72) & (0.017) \\ 3.50 & 3.52 & 3.49 & 0.030 * \\ (0.73) & (0.74) & (0.72) & (0.017)\end{array}$

Performance

10.56

10.67

10.48

$0.186 * * *$

(1.72)

(0.041)

Re-scaled performance

\section{Cronbach's alpha}

Obs.

7,502

4,296

Note. Means are derived using 5-point scale where $1=$ much worse than others, $2=$ worse than others, $3=$ about the same as others, $4=$ better than others, and $5=$ much better than others. Standard deviations are in parentheses. The re-scaled performance measure is within the unit interval from the formula: $($ anti + perf + prod -3$) / 12$ 


\begin{tabular}{|c|c|c|}
\hline & $\begin{array}{l}\text { Gender } \\
\text { Difference }\end{array}$ & $\%$ of Std. \\
\hline Married & $\begin{array}{l}0.0625^{* * *} \\
(0.0108)\end{array}$ & $13 \%$ \\
\hline Age & $\begin{array}{l}0.3880 * \\
(0.2218)\end{array}$ & $4 \%$ \\
\hline Years of Schooling & $\begin{array}{l}0.2329 * * * \\
(0.0532)\end{array}$ & $8 \%$ \\
\hline Job Tenure & $\begin{array}{l}-0.4950 * * * \\
(0.1478)\end{array}$ & $6 \%$ \\
\hline Holding Multi-jobs & $\begin{array}{l}0.0428 * * * \\
(0.0071)\end{array}$ & $13 \%$ \\
\hline Unemployment Experience & $\begin{array}{l}0.0024 \\
(0.0095)\end{array}$ & $1 \%$ \\
\hline Performance & $\begin{array}{l}0.0050 \\
(0.0031)\end{array}$ & $3 \%$ \\
\hline Locus of Control & $\begin{array}{l}0.0167 * * * \\
(0.0027)\end{array}$ & $13 \%$ \\
\hline $\mathrm{C}-\mathrm{A}$ & $\begin{array}{l}0.0105 * * * \\
(0.0026)\end{array}$ & $8 \%$ \\
\hline Work Ethic & $\begin{array}{l}0.0072 * * * \\
(0.0024)\end{array}$ & $6 \%$ \\
\hline Being a Supervisor & $\begin{array}{l}0.0869 * * * \\
(0.0101)\end{array}$ & $18 \%$ \\
\hline Ever Receiving Promotions & $\begin{array}{l}0.0264 * * \\
(0.0106)\end{array}$ & $5 \%$ \\
\hline
\end{tabular}

Note. $* * * \mathrm{p}<0.01, * * \mathrm{p}<0.05, * \mathrm{p}<0.1$. The percentages are calculated based on the standard deviations reported in Tables $1-4$.

Appendix Table A3: Effects of Non-Cognitive Traits on Supervisory Status and Promotion, Average Partial Effects from Probit Model 
(1)

\begin{tabular}{|c|c|c|c|c|}
\hline \multirow[b]{2}{*}{ Female } & \multicolumn{2}{|c|}{ Supervisor } & \multicolumn{2}{|c|}{ Promotion } \\
\hline & $\begin{array}{l}-10.42 * * * \\
(1.40)\end{array}$ & $\begin{array}{l}-9.66 * * * \\
(1.35)\end{array}$ & $\begin{array}{l}-3.59 * * \\
(1.49)\end{array}$ & $\begin{array}{l}-2.99 * * \\
(1.49)\end{array}$ \\
\hline Married & $\begin{array}{l}6.30 * * * \\
(1.17)\end{array}$ & $\begin{array}{l}6.03 * * * \\
(1.16)\end{array}$ & $\begin{array}{l}2.42 * * \\
(1.20)\end{array}$ & $\begin{array}{l}2.37 * * \\
(1.20)\end{array}$ \\
\hline Age & $\begin{array}{l}1.97 * * * \\
(0.42)\end{array}$ & $\begin{array}{l}2.12 * * * \\
(0.41)\end{array}$ & $\begin{array}{l}0.53 \\
(0.45)\end{array}$ & $\begin{array}{l}0.60 \\
(0.45)\end{array}$ \\
\hline Age Squared & $\begin{array}{l}-0.02 * * * \\
(0.00)\end{array}$ & $\begin{array}{l}-0.02 * * * \\
(0.00)\end{array}$ & $\begin{array}{l}-0.01 \\
(0.01)\end{array}$ & $\begin{array}{l}-0.01 \\
(0.01)\end{array}$ \\
\hline Job Tenure & $\begin{array}{l}2.01 * * * \\
(0.32)\end{array}$ & $\begin{array}{l}2.06 * * * \\
(0.32)\end{array}$ & $\begin{array}{l}3.84 * * * \\
(0.38)\end{array}$ & $\begin{array}{l}3.89 * * * \\
(0.38)\end{array}$ \\
\hline Job Tenure Squared & $\begin{array}{l}-0.05 * * * \\
(0.01)\end{array}$ & $\begin{array}{l}-0.05 * * * \\
(0.01)\end{array}$ & $\begin{array}{l}-0.07 * * * \\
(0.01)\end{array}$ & $\begin{array}{l}-0.07 * * * \\
(0.01)\end{array}$ \\
\hline Unemployment & $\begin{array}{l}-5.36 * * * \\
(1.58)\end{array}$ & $\begin{array}{l}-5.22 * * * \\
(1.56)\end{array}$ & $\begin{array}{l}-4.74 * * * \\
(1.55)\end{array}$ & $\begin{array}{l}-4.71 * * * \\
(1.56)\end{array}$ \\
\hline Holding Multi-jobs & $\begin{array}{l}4.19 * * \\
(1.77)\end{array}$ & $\begin{array}{l}3.94 * * \\
(1.75)\end{array}$ & $\begin{array}{l}4.29 * * \\
(1.93)\end{array}$ & $\begin{array}{l}4.09 * * \\
(1.90)\end{array}$ \\
\hline Years of Schooling & $\begin{array}{l}2.04 * * * \\
(0.33)\end{array}$ & $\begin{array}{l}1.87 * * * \\
(0.31)\end{array}$ & $\begin{array}{l}2.05 * * * \\
(0.28)\end{array}$ & $\begin{array}{l}1.93 * * * \\
(0.27)\end{array}$ \\
\hline Performance & $\begin{array}{l}50.98 * * * \\
(4.27)\end{array}$ & $\begin{array}{l}46.94 * * * \\
(4.19)\end{array}$ & $\begin{array}{l}37.78 * * * \\
(4.47)\end{array}$ & $\begin{array}{l}34.40 * * * \\
(4.45)\end{array}$ \\
\hline Locus of Control & & $\begin{array}{l}16.62 * * * \\
(4.76)\end{array}$ & & $\begin{array}{l}7.41 \\
(5.12)\end{array}$ \\
\hline $\mathrm{C}-\mathrm{A}$ & & $\begin{array}{l}19.48 * * * \\
(4.68)\end{array}$ & & $\begin{array}{l}24.36^{* * *} \\
(5.11)\end{array}$ \\
\hline Work Ethic & & $\begin{array}{l}30.16^{* * * *} \\
(5.47)\end{array}$ & & $\begin{array}{l}14.35^{* * *} \\
(5.78)\end{array}$ \\
\hline Obs. & 7,460 & 7,460 & 7,502 & 7,502 \\
\hline R-squared & 0.28 & 0.28 & 0.28 & 0.28 \\
\hline
\end{tabular}

Note. All regressions include workplace fixed effects. The estimates are multiplied by 100 and can be interpreted as percentage points. Robust standard errors are reported in parentheses, and they are clustered at the workplace level. $* * * \mathrm{p}<0.01, * * \mathrm{p}<0.05, *$ $\mathrm{p}<0.1$ 


\section{Supervisor}

Female

Married

Age

Age Squared

Job Tenure

Job Tenure Squared

Unemployment

Holding Multi-jobs

Years of Schooling

Performance

Locus of Control

C-A

Work Ethic
(1)

(2)

\begin{tabular}{|c|c|}
\hline$-10.46 * * *$ & $-9.72 * * *$ \\
\hline (1.40) & $(1.36)$ \\
\hline $6.22 * * *$ & $5.98 * * *$ \\
\hline (1.19) & (1.17) \\
\hline $2.04 * * *$ & $2.18 * * *$ \\
\hline
\end{tabular}

(3)

$$
(0.42)
$$

$-0.02 * * *$

$(0.00)$

$2.10 * * *$

(0.33)

$-0.05 * * *$

$(0.01)$

$-5.27 * * *$

(1.58)

$3.57 * *$

(1.74)

$1.98 * * *$

(0.34)

$46.41 * * *$

(4.21)

$16.66 * * *$

(4.73)

$18.96 * * *$

(4.63)

$29.67 * * *$

(5.42)
(4)

Promotion

$-3.66^{* *} \quad-3.10 * *$

(1.48) (1.48)

$2.41 * * \quad 2.37 * *$

(1.21) (1.20)

$0.57 \quad 0.63$

$(0.46) \quad(0.46)$
-0.01

$-0.01 \quad-0.01$

$(0.01) \quad(0.01)$

$3.87 * * * \quad 3.91 * * *$

$(0.39) \quad(0.38)$

$-0.07 * * * \quad-0.07 * * *$

(0.01) (0.01)

$-4.56 * * * \quad-4.55 * * *$

(1.55) (1.56)

$4.45 * * \quad 4.25 * *$

(1.94) (1.91)

$2.15 * * * \quad 2.02 * * *$

(0.29) (0.28)

$37.78 * * * \quad 34.51 * * *$

(4.53)

(4.50)

6.65

(5.16)

$24.31 * * *$

(5.16)

$14.41 * *$

(5.84)

Obs.

7,460

7,460

7,502

7,502

R-squared

0.28

0.28

0.28

0.28

Note. All regressions include workplace fixed effects. The estimates are multiplied by 100 and can be interpreted as percentage points. Robust standard errors are reported in parentheses, and they are clustered at the workplace level. $* * * \mathrm{p}<0.01, * * \mathrm{p}<0.05$, * $\mathrm{p}<0.1$ 
Women

\begin{tabular}{|c|c|c|c|}
\hline State-owned & Private-owned & State-owned & Private-owned \\
\hline$-8.40 * * *$ & $-9.78 * * *$ & -1.07 & $-3.67 *$ \\
\hline
\end{tabular}

Married

$$
\text { (1.73) }
$$

(2.09)

(2.09)

(2.13)

$6.14 * * *$

$5.25 * * *$

1.31

2.36

(1.71)

(1.67)

(1.79)

(1.66)

$1.78 * * *$

$1.61 * * *$

0.32

0.94

Age

(0.58)

(0.58)

(0.57)

(0.66)

Age Squared

$-0.01 *$

$-0.01 *$

$-0.00$

$-0.01$

(0.01)

(0.01)

(0.01)

(0.01)

Job Tenure

$1.50 * * *$

$2.96 * * *$

$3.36 * * *$

$4.69 * * *$

Job Tenure Squared

(0.46)

(0.46)

(0.53)

(0.53)

$-0.03 * * *$

$-0.07 * * *$

$-0.05 * * *$

$-0.09 * * *$

(0.01)

(0.01)

(0.01)

(0.01)

Unemployment

$-0.41$

$-6.86^{* * *}$

$-7.29 * * *$

$-2.73$

(2.43)

(1.79)

(2.35)

(2.08)

Holding Multi-jobs

$6.91 * * *$

1.01

$5.62 *$

2.70

(2.54)

(2.52)

(3.06)

(2.49)

Years of Schooling

$0.94 * *$

$3.11 * * *$

$1.51 * * *$

2.46***

(0.37)

(0.47)

(0.39)

(0.40)

Performance

42.28***

$48.52 * * *$

$26.59 * * *$

$38.85 * * *$

(5.97)

(6.36)

(6.00)

(6.53)

Locus of Control

$19.32 * * *$

$17.73 * * *$

$22.45^{* * *}$

$23.31 * * *$

(6.78)

(6.43)

(8.57)

(6.49)

$19.44 * * *$

13.04*

3.10

9.97

(6.66)

(8.02)

(6.44)

$30.09 * * *$

$25.22 * * *$

12.16

$13.39 *$

(7.29)

(8.74)

(7.56)

Gender Gap

Explained by Non-

0.74

0.68

0.51

0.37

Cognitive Traits

(8.5\%)

(6.8\%)

(32.3\%)

(13.6\%)

Obs.

3,283

4,177

3,314

4,188

R-squared

0.24

0.33

0.28

0.29

Note. All regressions include workplace fixed effects. The estimates are multiplied by 100 and can be interpreted as percentage points. Robust standard errors are reported in parentheses, and they are clustered at the workplace level. We calculate the gender gap explained by noncognitive traits by comparing the estimated gender gap in this table with the estimated gender gap from regressions without controlling for non-cognitive traits. *** $\mathrm{p}<0.01, * * \mathrm{p}<0.05, *$ $\mathrm{p}<0.1$ 